\title{
Towards an Ethics of Technology: Re-Exploring Teilhard de Chardin's Theory of Technology and Evolution
}

\author{
Archimedes C. Articulo \\ College of Arts and Sciences, Cagayan State University, Tuguegarao City, Philippines \\ Email: chitocsu@gmail.com
}

Received 7 September 2014; revised 28 September 2014; accepted 8 October 2014

Copyright (C) 2014 by author and Scientific Research Publishing Inc. This work is licensed under the Creative Commons Attribution International License (CC BY). http://creativecommons.org/licenses/by/4.0/ (c) (7) Open Access

\section{Abstract}

Defining the mechanism of evolution is a controversial issue that, until now, divides the scientific community. Some have argued in the strictest Darwinian terms that evolution's primary mechanism is necessity- "survival of the fittest". Other evolutionists followed in the footsteps of Jacques Monod, the French biologist, who argued for a mixture of random chance and necessity. Teilhard de Chardin, it is widely believed, took Monod one step further by asserting that evolution is the fundamental motion of the entire universe, an ascent along a privileged and necessary pathway toward consciousness - thus, evolution was guided chance and necessity. However, if evolution is being guided, what is doing the guiding? And where, ultimately, is it going? His bold answers brought Teilhard to the heart of a widely perceived scientific, as well as religious, heresy. A heresy that was effectively silenced, and soon would re-emerge as the world began witnessing exponential advancements in Science and Technology (specifically, on computing, nano-technology, robotics and genetic engineering). Almost half a century after the publication of Phenomenology of Man, many futurist thinkers have began noticing that the super-fast acceleration in the passage of time for evolution is moving in a very different direction than that for the Universe from which it emerges. This paper puts forward the thesis that the philosophical underpinning of a "humansponsored variant of evolution" (i.e. evolution towards convergence of biological and non-biological intelligence) finds support and meaning within Teilhard de Chardin's theory of evolution (i.e. evolution towards consciousness). It specifically covers 1) the implications of advancing technologies in human evolution and consciousness within the context of Teilhard's theory of evolution; 2) how, after homo sapiens silently emerged around 500,000 years ago (with larger brains, particularly in the area of the highly convoluted cortex responsible for rational thought), and after they develop computing, the story of evolution has progressed exponentially paving the way for the possibility of turning Teilhard's controversial ideas (such as the Noosphere) more than a poetic image; and 3) how the grandest creations of evolution-consciousness and intelligence-provide for the very tool that may allow homo sapiens to take over the course and direction of their own 
evolution-without necessarily shedding their desire to search for spiritual truth in a secular universe.

\section{Keywords}

Technology, Ethics, Singularity, Brain-Computer Interface, Trans-Humanism, Teilhard de Chardin, Religion, Philosophy of Religion

\section{The Need for Ethics of Technology}

The tremendous power of the $21^{\text {st }}$ century Technology bestows its creator the capability to intervene significantly on the mechanisms of life, including the power to wipe the same, on the face of this planet. We, humans, have unlocked the power of the atom and probed deeply on the secrets of the building blocks of life, and we are ready, literally, to actively design our own, and other species', evolutionary transformations and destinies.

The most prominent of the emerging views on the implications of modern technology is transhumanism. We might not know it, but in some forms, we unconsciously hold its basic premises.

Transhumanism is the belief that humans must wrest their biological destiny from evolution's blind process of random variation and adaptation and move to the next stage as a species, favoring the use of science and technology, especially neurotechnology, biotechnology, and nanotechnology, to overcome human biological limitations. It asserts that we are no longer the passive subject of natural evolution because we are capable of becoming, and we should endeavor to become, the masters of our own evolution. Its ultimate goal is human immortality through the use of highly advance human technology. And for good reasons, this horrifies many of us.

Imagine the havoc which a rebellious, irresponsible, violent, and immortal human could do to his Universe.

The exponential rate of advancement of our science and technology become alarming and disturbing because it is widely believed that for every new scientific discovery and for every introduction of new technology, the gulf between the states of our technological maturity and moral adolescence widens. And the gulf is widening in a very fast and confusing pace. We are like intolerant, impulsive, hotheaded, thrill-seeking and immature adolescents who were given guns and bombs, with ever increasing power, to play with.

Many thoughtful people have concluded that Mankind must be stopped from its dangerous craving for technological power.

However, is it really the time to exorcise, or to tamper, the demon of discovery?

Unlike many people during his time who witnessed the horrors of the unleashing of Atomic weapons on Hiroshima and Nagasaki, Teilhard de Chardin, a Jesuit priest and a scientist, saw something especial in mankind trying to cross the realm of the gods. Where others saw horrors, Teilhard saw the expression of human evolution in a brand new dimension: humanity is entering a peculiarly critical phase of super-humanization, we are evolving into a global mind.

All the chaotic processes of inventions and innovations which never fail to baffle most of us are transformed into a meaningful whole under the radical Philosophy of Teilhard: they become the manifestations of an increasingly rapid growth in the human world of the forces of collectivization, the "super arrangement", or the megasynthesis.

There is, I think, no other age but ours, which urgently needs an ethical framework, system, or philosophy, that could guide us in our quest for technological advancements-whether it is always, never, or contextually right or wrong to invent and implement technological innovations. Here, the Philosophy of Teilhard de Chardin offers an interesting and refreshing alternative to other mainstream and pessimistic views on Science and Technology, that as students of Philosophy, we should endeavor to explore.

This paper argues that:

1) The philosophical underpinning of a transhumanist's "human-sponsored variant of evolution" (i.e. evolution towards convergence of biological and nonbiological intelligence) finds support and meaning within Teilhard's theory of evolution (i.e. evolution towards consciousness), however-

2) Teilhard's theory of evolution could well show the absurdity of transhumanist ultimate ideal of human immortality. 


\section{Evolution of Consciousness}

Teilhard's theory is deceptively simple: it revolves around the idea of an evolutionary progression towards greater and greater consciousness, until it reaches an ultimate stage which he called the Omega Point.

In The Phenomenon of Man (recently, retranslated as The Human Phenomenon), Teilhard provided two equations, which according to him, have been gradually formulating themselves from the moment he began situating the phenomenon of man in the world ${ }^{1}$ :

Evolution = Rise of consciousness;

Rise of consciousness $=$ Union effected.

For Teilhard, Matter and consciousness are the two subjects of evolution. Matter is the edifice, the cradle of consciousness-and consciousness becomes more perfected as it finds a richer and better organized material structure.

As such, Teilhard calls matter and consciousness, the "Without" and "Within" respectively, which are held together by one single, universal energy ${ }^{2}$. Evolution is the steady increase in the "Within" through the growing complexity of "Without", through a number of successive stages ${ }^{3}$. Teilhard follows the evolutionist understanding of an evolutionary progression from inanimate matter (i.e. atoms and molecules) through primitive life and invertebrates to fish, amphibia, reptiles, mammals, then, man, and finally the Omega point ${ }^{4}$.

However, it must be stressed that for Teilhard, it is with the coming of man where the first significant threshold is crossed-because for the first time in the long story of evolution matter becomes a thinking, self-conscious entity. With the appearance of man, thought or mind, appears. Man, the child of progress, the youngest in the evolutionary tree, stands apart from other animals, for he rises no longer merely to know, but to know that he knows ${ }^{5}$. In other words, from the coming of Man, biological evolution not only rebounds but it rebounds reflectively upon itself. In Man evolution is interiorized and made purposeful. In man, the spiritualization of matter began.

What is in man which is the sign and measure of his reflective powers, the crowning glory of evolution? The key concept here is "celebralization": the "cephalization" of organisms. The more the nervous system develops the more conscious the living entity becomes ${ }^{6}$. In Future of Mankind, Teilhard writes:

"While accepting the undeniable fact of the general evolution of Life in the course of time, many biologists still maintain that these changes take place without following any defined course, in any direction and at random. This contention, disastrous to any idea of progress, is refuted, in my view, by the tremendous fact of the continuing 'cerebralization' of living creatures. Research shows that from the lowest to the highest level of the organic world there is a persistent and clearly defined thrust of animal forms towards species with more sensitive and elaborate nervous systems...”7

From the ceaseless noises of his brain arose the stone tools, the discovery and taming of the fire, the writing of the Bible, the discovery of evolution, the Atomic Bomb, the invention of the computer and of the internet, the

\footnotetext{
${ }^{1}$ Teilhard de Chardin. (1975). The Phenomenon of Man. Harper \& Row, publish. New York. p. 243.

${ }^{2}$ Speaking about this universal energy operating in the world, Teilhard said that it is psychic in nature-however, in each particular element it is divided into two distinct component: a tangential energy which links the element with all others of the same order, and a radial energy which draws it towards ever greater complexity and centricity-in other words, forwards. In Chapter 3 of Phenomenon of Man, Teilhard equates "psychic energy" with "radial" energy which operates beneath and within the mechanical or "tangential" energy. The boiling and the eventual bursting of psychic energy is the reason for the "explosion" of Life upon the early earth-which culminated into the coming of Man.

${ }^{3}$ And therefore, Spiritual perfection (greater consciousness, or conscious “centreity”) and material synthesis (or complexity) are but the two aspects or connected parts of one and same phenomenon. See The Phenomenon of Man, p. 60; See also Teilhard's The Future of Mankind. (1959). Harper \& Row, New York and Evanston. Chapter 3.

${ }^{4}$ So pre-living entities are ordered on Earth in the lithosphere, the hydrosphere, and the atmosphere. Organic beings make up the biosphere, and thinking entities (which in Teilhard's system solely means man) the noosphere. The Omega point, or the Mega-Synthesis is the final stage of evolution where humans are united in a single Divine Christ-consciousness.

${ }^{5}$ The Future of Mankind, Ch. 10, Part I.

${ }^{6}$ Here, I was constrained to ignore the contemporary debates in Anglo-American analytic philosophy regarding the meaning and nature of consciousness in order to explore fully the implications of the Chardinian concept of consciousness to the transhumanist's vision of humanmachine convergence. It must be noted however that the scientific and philosophical study of the human consciousness in the modern time has resulted into refined approaches, which include mysterianism, dualism, representationalism, higher-order monitoring theory, and the self-representational theory. For a good survey of the modern theories of consciousness, see Kriegel, U. (2007). Theories of Consciousness, in Cambridge Handbook of Consciousness, Moscovitch, M., Thomspon, E. and P.D. Zelato (eds.). Cambridge University Press.

${ }^{7}$ The Future of Mankind, Ch. 4, Part 1 [4].
} 
exploration of the moon, genetic engineering, robotics, nanotechnology, the list is long and every day it's getting longer ${ }^{8}$. In other words, the employment of man's reflective powers has set into motion the evolution of his "exteriorized", nonbiological creation: his tools, his machines, his technology.

Man, one of the frailest in the animal kingdom, with his technology, has emerged to be the sole child of the Earth that enjoys tremendous mechanical competence. While successfully extending, increasing, and heightening man's mechanical efficiency, his tools, in the words of Teilhard, have also continuously liberated his thought of the trammels which hinder its progress ${ }^{9}$.

However, the human brain has reached the limits of its growing complexities at the stage of Homo Sapiens (around 500,000 years ago) $)^{10}$-did evolution of matter towards greater consciousness stop with it? For Teilhard, it did not. He points to the heightening organo-psychic development of man (i.e. the process of socialization) which began 30,000 years ago, as an indication that evolution marches ${ }^{11}{ }^{11}$. The process of super-molecularzation on the planet proceeded even when Matter attained in Homo sapiens its maximum of centro-complexity on Earth. The Individual man is evolving into the Collective Man.

Man, according to Teilhard, is at present time entering a peculiarly critical phase of super-humanization: the increasingly rapid growth in the human world of the forces of collectivization, the "super arrangement", or the mega-synthesis. In the Phenomenon of Man, Teilhard declares:

"The age of industry; the age of oil, electricity and the atom; the age of the machine, of huge collectivities and of science - the future will decide what is the best name to describe the era we are entering. The word matters little. What does matter is that we should be told that, at the cost of what we are enduring, life is taking a step, and a decisive step, in us and in our environment... To us, in our brief span of life, falls the honour and good fortune of coinciding with a critical change of the noosphere." 12

Humans, dwarfed by the Copernican revolution, but enlarged by Teilhard, are, in the literal (or biological) definition of the term, in the verge of creating the Noosphere-the thinking layer of the Earth.

\section{The Noosphere and the Cyberspace}

In the Phenomenon of Man, Teilhard described his now famous concept of the Noosphereas follows:

"The idea is that of the earth not only becoming covered by myriads of grains of thought, but becoming enclosed in a single thinking envelope so as to form, functionally, no more than a single vast grain of thought on the sidereal scale, the plurality of individual reflections grouping themselves together and reinforcing one another in the act of a single unanimous reflection." ${ }^{13}$

Unlike the contemporaries of Teilhard in 1940's when satellite communications still dwell in the realm of science fiction, the $21^{\text {st }}$ century readers could easily identify the Noosphere with the idea of a "cyberspace", a term used by the computer press in reference to that mystical field of inter-connecting computer pathways wherein all of the exchanges are made. As the cyberspace is as real as the physical space, in the same manner, the Noosphere, for Teilhard, is real and not just a poetic image:

"The first thing to give us pause, as we survey the progress of human collectivization, is what I would call the inexorable nature of a phenomenon which arises directly and automatically out of the conjunction of two factors, both of a structural kind: first, the confined surface of the globe, and secondly, the incessant multiplication, within this restricted space, of human units endowed by ever-improving means of commu-

\footnotetext{
${ }^{8}$ It is a well-known fact that humans are not alone in their use or even creation of tools-for instance, orangutans in Sumatra's Suaq Balimbing swamp make tools out of long sticks to break open termite nests, the leaf-cutter ant mixes dry leaves with its saliva to create a paste, etc.- however, human technology is different for it goes beyond the mere fashioning and use of tools because it involves a record of tool making and a progression of its sophistication, in other words, innovation.

${ }^{9}$ The Future of Man. Ch. 10, Part 1. [2-c].

${ }^{10}$ Teilhard noted in The Future of Mankind that the human brain may still be biologically evolving in ways our current means of measurement can not, at least in the present time, physically detect. See Chapter 4, Part I [6].

${ }^{11}$ The cave-dwelling man and the modern man may not differ in terms of the structure of their brains. But what marks them apart, according to Teilhard, is the complexity of their social organization, in other words, their state of concentration. The birth of the tribes, of the empires, and of the modern states is therefore the offspring of the great movement of evolution towards socialization or collectivization. See The Future of Mankind, Ch. 4, Part I [6].

${ }^{12}$ The Phenomenon of Man, p. 243.

${ }^{13}$ Ibid., p. 251.
} 
nication with a rapidly increasing scope for action; to which may be added the fact that their advanced psychic development makes them preeminently capable of influencing and inter-penetrating one another ${ }^{14}$. [Emphasis supplied].

Man, as previously noted, is one of the frailest in the animal kingdom, but he gained tremendous strength from his conscious effort of drawing close to his kind, of communicating, and finally of uniting. The birth of the tribes, of the city-states, of empires, of the modern states, and the emergence of international organizations in the $20^{\text {th }}$ century, stand witness of our predilection of communicating and of uniting. And it is hardly debatable that this desire of coming together is heightened, and the means accelerated, by our technology.

Even when the mechanical apparatus of the Noosphere was still young during his time, Teilhard has fully appreciated the role which machines play in the future deployment of the Noosphere. Teilhard, in The Phenomenon of Man, writes:

"Through the discovery yesterday of the railway, the motor car and the aeroplane, the physical influence of each man, formerly restricted to a few miles, now extends to hundreds of leagues or more. Better still: thanks to the prodigious biological event represented by the discovery of electro-magnetic waves, each individual finds himself henceforth (actively and passively) simultaneously present, over land and sea, in every corner of the earth." 15

And in the Future of Man, Teilhard points to the early radio and television technology, which is only capable at that time of providing for local coverage (i.e. covering only a few square miles), and the computer, the full potential of which still resides in the theoretical realms in the early 40 ' ${ }^{16}$ :

"I am thinking, of course, in the first place of the extraordinary network of radio and television communications which, perhaps anticipating the direct inter-communication of brains through the mysterious power of telepathy, already link us all in a sort of 'etherized' universal consciousness. But I am also thinking of the insidious growth of those astonishing electronic computers which, pulsating with signals at the rate of hundreds of thousands a second, not only relieve our brains of tedious and exhausting work but, because they enhance the essential (and too little noted) factor of 'speed of thought', are also paving the way for a revolution in the sphere of research...,"17

Today, man has in his disposal an array of highly advanced communication and transportation technologies, which are rapidly shrinking the world as they continuously evolve to be more efficient, fast, and powerful.

The $21^{\text {st }}$ century man, through his machines-most especially the computer-has already assembled a truly global network of relations, activities, and concerns in the spheres of trade, politics, accumulation and exchange of knowledge, and cooperative research, whose present forms the man of the 40's may not even imagine to be possible.

\section{Technology and the Convergence of Hearts}

Central to the thesis of Teilhard is his concept of convergence. The chaos which usually characterize the independent achievements and activities of man, for Teilhard, should be seen as phenomena that occurs and move, in its entirety, towards union or uniformity. It is like the coordinated movement of the two eyes so that the image of a single point is formed on corresponding retinal areas.

Convergence, according to Teilhard, does not manifest itself explicitly, but may be seen as an overall effect of multifarious and interdependent causes.

Let us consider some of the various manifestations of convergence or, what Teilhard sometimes refer to as "collectivization".

We begin with Education as we know it today. No individual knows more than a tiny fraction of the sum of human knowledge, and each scholar is dependent not only for his education but for all his subsequent work on

\footnotetext{
${ }^{14}$ The Future of Mankind, Ch. 6, Part III.

${ }^{15}$ The Phenomenon of Man, p. 240.

${ }^{16}$ The most advanced computer during Teilhard's time was the Electromechanical (Relay Based) Computers (Zuse 3). This evolved into the vacuum-tube-based computers of the 1950s, then to the transistor-based machines of the 1960s, and to all of the generations of integrated circuits of the past four decades. Computers today are a lot much smaller but about one hundred million times more powerful than they were a half century ago.

${ }^{17}$ The Future of Mankind, Ch. 6, Part III.
} 
the traditions and resources which are the collective possession of an entire international society composed of the living and the dead.

In the past, he relies on the limited number of books and journals shelved in the corners of a local or university library, now, he could access a global library of information and resources in a blink of an eye anytime, anywhere, via the "Cyberspace". Just as Earth once covered itself with a film of interdependent living organisms which we call the biosphere, so mankind's combined achievements in our present age are forming a global network of collective mind. Human knowledge and information, the product of man's reflective power, becomes more "Noospheric" than ever before.

Next, consider how our world adopts the invention and introduction of new discoveries, leading to their exponential, or accelerating development. Teilhard has described it well in The Future of Man, that we could present his discussion here without leaving our experience of our $21^{\text {st }}$ century technology:

"Every new tool conceived in the course of history, although it may have been invented in the first place by an individual, has rapidly become the instrument of all men; and not merely by being passed from hand to hand, spreading from one man to his neighbor, but by being adopted corporatively by all men together. What started as an individual creation has been immediately and automatically transformed into a global, quasi-autonomous possession of the entire mass of men. We see this from prehistoric times, and we see it with a vivid clarity in the present era of industrial explosion.,"18

Think of the automobile, or the television, or the personal computers or cellular phones, or software like the Windows 7-anything - what does it show us? Accelerating adoption of technology and innovation, which leads to its exponential development and evolution. Note that the progress of technology in the nineteenth century, greatly exceeded all the technological progress since the appearance of the Homo sapiens ${ }^{19}$. But the continued exponential growth of technology in the first two decades of the twentieth century matched that of the entire nineteenth century. In the $21^{\text {st }}$ century, we have major transformations in just a few years' time. As one of many examples, the latest revolution in communications-the World Wide Web-didn't exist just a few years ago ${ }^{20}$. This worldwide reception of a tool or a method invented or developed usually by one man, or one group of men, clearly demonstrates a "Noospheric" adoption.

Now, consider the growth of our collective consciousness. With global coverage of television networks, which is made possible by the discovery of geosynchronus satellite communications technology ${ }^{21}$, and the widespread connection of people around the world in the Internet, a worldwide feeling of responsibility, at least an interest for things that happen elsewhere on this globe, now becomes too apparent among humans to be ignored. Our rising awareness and concerns for environmental protection; the millions of Catholic faithful around the world who grieved for the death of Pope John Paul II and who patiently waited for the Habemus Papam pronouncement in 2005; the collective response of the world after the American invasion of Iraq in 2003, and in the outpouring of sympathy for the victims of the Asian tsunami disaster of 2005, and the worldwide condemnation of Israel for its attacje on Gaza in 2008, among many others, clearly demonstrates a "Noospheric" reaction.

Note that these three trends of growing collectivity perfectly follow the requirement of Teilhard that a genuine convergence is not a convergence of merely minds or bodies - but of hearts, a point he fervently made in almost all of his works ${ }^{22}$. Our desire for more being and meaning, the ever-growing thirst for greater knowledge, and the tremendous power of our technology to connect and unite people-are gradually making our age "noospheric".

Assuming we don't misuse our technology and blow ourselves to kingdom come, the perfection, at least of the material support, of the Noosphereis within reach in few decades as guaranteed by the Law of Accelerating

\footnotetext{
${ }^{18}$ The Future of Mankind, Ch. 10. Part 1.

${ }^{19}$ With the building of canals and great ships, the advent of paved roads, the spread of the railroad, the development of the telegraph, and the invention of photography, the bicycle, sewing machine, typewriter, telephone, phonograph, motion picture, automobile, and of course Thomas Edison's light bulb.

${ }^{20}$ Kurzweil, R. (1999). The Age of Spiritual Machines: When Machine Intelligence Exceeds Human Intelligence. London: Penguin Book, Ltd p. 8.

${ }^{21}$ The idea of a geosynchronus satellite communication system was first proposed in 1944 by Sir Arthur C. Clarke, a Physicist, Space visionary, and Science fiction writer (His popular works include 2001: A Space Odyssey; Childhood's End; and Fountain of Paradise). The 22,000 miles orbit where our satellites $d w e l l$ is named "Clarke's Orbit" in his honor.

${ }^{22}$ A point that he made fervently in Phenomenology of Man: men united by love, or sympathy, in other words, a union without losing individuality. See The Phenomenon of Man, pp. 257-267; The Future of Mankind, Ch. 6, Part III.
} 
Returns - a law of evolutionary processes that the scientific community is now starting to recognize, and to which we must now explore ${ }^{23}$.

\section{The Law of Accelerating Returns and the Coming of Human-Machine Convergence}

The Law of Accelerating Returns describes evolution (like biological and technological evolutions) as a process that builds on its own increasing order ("order" here means how well the information fits a purpose). As the order increases, time speeds up, and as order and time speed up, the returns (that is, the valuable products of the process) accelerate. Evolution applies positive feedback in that the more capable methods resulting from one stage of evolutionary progress are used to create the next stage. An evolutionary processes therefore, assuming that it is not wholly wiped out, will accelerate exponentially through time.

As applied to the evolution of technology, the Law of Accelerating Returns states that as order exponentially increases, the time interval between salient technological development grows shorter as time passes ${ }^{24}$. For example, the time invested for the invention of the first generation of technology $\mathrm{X}$ (say, developed for 16 years) will allow for the development of a more powerful second generation of technology $\mathrm{X}$ (now only for 4 years), and for succeeding generations of the same technology (for 2 years) with increasing power. The windfall of this is the speeding up of other technologies that make use of the already exponentially developing technology (e.g. research on genetic engineering or robotics via super computers). With more powerful computers and related technology, we have the tools and the knowledge to design yet more powerful computers and related technology, and to do so more quickly. There are a great many examples of the exponential growth implied by the law of accelerating returns in technologies as varied as DNA sequencing, communication speeds, electronics of all kinds, and most especially in the rapidly shrinking size of technology.

And so, just like the exponential growth of the evolution of life, which builds on its past achievements as encoded in the DNA, the technological evolutionary process accelerates because it also builds on its past achievements (encoded in the collective knowledge base of mankind, the genetic code for the evolving technology), which includes improvements in its own means for further evolution.

Our researchers have already exhaustively mapped the physical regions of the human brain (and are increasingly demystifying the mind), decoded the human DNA (and are preparing to tinker it), we are making our machines exceed the computational speed of our own brains, we make interactive robots to look, speak, and act like us, we are now in the level of manipulating atoms, and we have started to build complex atomic artifacts, and we are introducing, replacing, and converging powerful machines with our bodies.

The interplay and myriad synergies of $21^{\text {st }}$ century technology, the intense human drama of innovation and competition, all these chaotic processes, never fail to baffle most of us. But in Teilhard they could be transformed into a meaningful whole: we are building a global mind.

"From west to east, evolution is henceforth occupied elsewhere, in a richer and more complex domain, constructing, with all minds joined together, mind. Beyond all nations and races, the inevitable taking-as-awhole of mankind has already begun. We can envisage a world whose constantly increasing 'leisure' and heightened interest would find their vital issue in fathoming everything, trying everything, extending everything." ${ }^{25}$ [emphasis supplied].

\footnotetext{
${ }^{23}$ First proposed by Ray Kurzweil in his book "The Age of Spiritual Machines" (1999). The exponential trend of the evolution of machines is also noted by Hans Moravec in "Mind Children: The Future of Robot and Human Intelligence" (1988), Bill Joy in "Why the Future Does not Need Us" (2002), Arthur Clarke in "The Profiles of the Future" (1962, 1973; 2000), and even Alvin Toffler in "Future Shock" (1972) and "The Third Wave" (1980), among many others.

${ }^{24}$ As applied to biological evolution, Kurzweil explains that as order (which for Darwin, is survival, and for Teilhard, greater consciousness) increases, the time interval between biological developments grows shorter as time passes. While evolution took billions of years to design the first primitive cells, when evolution invented the DNA to record the result of the "trial and error", or, in the words of Teilhard, "groping" made by Life, salient events then began occurring in hundreds of millions of years, a distinct quickening of the pace. The establishment of basic body plans of modern animals in the "Cambrian explosion", about 570 million years ago, allowed evolution to concentrate on higherlevel features such as expanded brain function. When some calamity finished off the dinosaurs 65 million years ago, mammals inherited the Earth. With the emergence of the primates, progress was then measured in mere tens of millions of years. Humanoids emerged 15 million years ago, distinguished by walking on their hind legs. Only around 500,000 years ago, Homo sapiens, our own species, emerged with larger brains, particularly in the area of the highly convoluted cortex responsible for rational thought. See Ray Kurweil, The Age of Spiritual Machines, Ch. 1 and his article, The Law of Accelerating Returns, the electronic version of the article could be downloaded at http://www.kurzweilai.net.

${ }^{25}$ The Phenomenology of Man, p. 278.
} 
The exponential growth of human technology presses forward man into thirsting to know more, to do more, to transform every matter he touches, and in the process, transforming himself:

"All the increasing degree, in which present-day thought and activity are influenced by the passion for discovery; the progressive replacement of the workshop by the laboratory, of production by research, of the desire for well-being by the desire for more-being points to the growth in our souls of a great impulse towards super-evolution.,26

For the eyes of someone imaginative enough to see where the heightened interest of man in trying everything, coupled with the exponential rate of the evolution of his technological capability, is headed, one will notice that human evolution is moving in a very different direction than that for the Universe from which it emerges: the enhancement of human consciousness through a technology-assisted enhancement of its biological vessel. The skeptics call it rubbish, the transhumanists call it convergence, but for those who define the homo sapiens purely in biological terms and who understand the profound implication, they call it extinction.

\section{Teilhard and the Transhumanist Concept of Biological Perfection}

When one seriously confronts the transhumanist ideal of Biological Perfection via human-machine convergence, two dominant reaction, which seems to present themselves in successive stages, usually emerge: the first, and the most popular, is outright denial-“man's technical capability will never reach the necessary level of sophistication to bring about the human-machine convergence", then comes horror and repugnance-“human-machine convergence is not only dehumanizing, but a threat to the survival of the human species."27

However, within the framework of Teilhard, one gets another, and refreshing view-hope: that they bestow man with more being (not only well-being) and more unity (not isolation), hope that all these technological advances that inevitably lead to the convergence of human and machine intelligence completes the material, even the cerebral, support of a genuine sphere of collective thought ${ }^{28}$. Surely, this requires a lot of explaining.

Recall the three specific cases we presented earlier concerning the advances we made in the $21^{\text {st }}$ century in realizing the material apparatus of the Noosphere (i.e. "noospheric" knowledge base, "noospheric" adoption of technology, and "noospheric" reaction). Now consider this thought experiment:

If technology, specifically the cyberspace and or the global satellite networks, connect people around the world simultaneously, and if technology, specifically the computer, mediates that global connection instantaneously, what happens if the computer is integrated in the human brain?

If this convergence is made possible, the combination of human reflective powers with a computer's inherent superiority in the speed, accuracy, and sharing ability of its memory will be formidable. As the humanbrain will be enhanced a million-fold, so is the human consciousness and intelligence.

But here, we may ask, how real is this human-machine convergence? The popular skepticism that men will never achieve the necessary technical ability to converge human and machine intelligence is usually met in the past, like in the time of Teilhard, with the too optimistic and wild extrapolations of our growing technical expertise. In our present age, it finds its firm empirical support. The technology required, it is true, is very complex, but the fact is-it's already here with us today-one only needs to survey the current developments in the field of brain prosthetics.

The accumulated data from the many decades of research in the cognitive sciences (most especially the research in neural recording and decoding), biotechonlogy, and Artificial Intelligence (A.I.), has found its decisive synthesis in the technical progress of Brain-Computer Interface (BCI) technology, now on its full-blown labor-

\footnotetext{
${ }^{26}$ The Future of Man, Ch. 6, Part III.

${ }^{27}$ Read Bill Joy, "Why The Future Does Not Need Us", Wired Magazine, Issue 8.04, copy available in the internet,

http://www.wired.com/wired/archive/8.04/. See also Francis Fukuyama, Posthuman Future: Consequences of the Biotechnology Revolution (2002); and his article, "Transhumanism" in Foreign Policy September-October 2004 issue, copy available in the internet:

http://www.foreignpolicy.com/story/cms.php?story_id=2667 See Brin, D. Singularities and Nightmare in Nanotechnology Perceptions: A Review of Ultraprecision Engineering and Nanotechnology, Volume 2, No. 1, March 27 2006,

http://www.kurzweilai.net/meme/frame.html?main=/articles/art0656.html [last accessed July 8, 2014: 4:00 pm].

${ }^{28}$ It is interesting to note here that Teilhard has described the Noosphere as a "stupendous" thinking machine: "Research, which until yesterday was a luxury pursuit, is in process of becoming a major, indeed the principal, function of humanity. As to the significance of this great event, I for my part can see only one way to account for it... As in the case of all the organisms preceding it, but on an immense scale, humanity is in process of "cerebralizing" itself... The Noosphere, in short, is a stupendous thinking machine." See The Future of Mankind, Ch. 6, Part IV, [c].
} 
atory development in many competing research centers around the world ${ }^{29}$.

On the morning of June 22, 2004, a Foxborough, Massachusetts-based company called Cyberkinetics officially began the most radical version of BCI to date-it seeks to prove that human brain-computer interfaces are possible and they can return function to people paralyzed by injury or disease. The fully functional system used in the conrtroversial clinical trial, was called Brain Gate, and one of the five human subjects was Matthew Nagle, 25, a C4 quadriplegic, paralyzed from the neck down ${ }^{30}$.

The following is the account of what happened when Nagel began using Braingate:

“As Nagle performed specific actions in his mind's eye-move arm left, move arm up-the electrodes picked up the patterns of nearby neuron groups. Then Brain Gate amplified and recorded the corresponding electrical activity. Over dozens of trials the computer built a filter that associated specific neural patterns with certain movements. Later, when Nagle again mentally pictured the motions, the computer translated the signals to guide a cursor. ... What are you thinking about when you move the cursor? I asked. 'For a while I was thinking about moving the mouse with my hand,' Nagle replied. 'Now, I just imagine moving the cursor from place to place.' In other words, Nagle's brain has assimilated the system. The cursor is as much a part of his self as his arms and legs were." ${ }^{\text {,31 }}$

Today, Nagel plays Pong, draw with a cursor, operate a TV, open email, and can open and close a prosthetic hand just by thinking about $\mathrm{it}^{32}$. Once you can control a computer cursor using your thought alone, anything could be made possible: from drawing circles in the computer monitor to lending a "voice" to a mute to allowing a quadriplegic to control his limbs. As Gerhard Friehs, the neurosurgeon who implanted Nagle's device claimed, with enough computational power, everything else is just engineering ${ }^{33}$. Last June 6, 2006, Cyberkinetics announced the commencement of the commercialization of the Braingate technology for disabled people, and its other product, Neuroport.

As applied to physically abled people, will they ever like the idea of bringing along a refrigerator-sized machine with red, yellow and white cables directly plucked to their brain? Part of the answer is miniurization: the process of shrinking the size of our technology, and at the same time making it powerful ${ }^{34}$. The thick coaxial cable and the refrigerator-sized machine involved in the Braingate system, in due time, is expected to shrink in more comfortable sizes that the entire system will ultimately appear merely as a nonbiological part of the scalp. The other part of the answer is non-evasive Brain-Computer Interfaces, which like the Braingate, are also under

\footnotetext{
${ }^{29}$ For a good survey of the current developments in BCI research, read Aileen Constans, Mind Over Machines: Brain-Machine Interfaces Help Locked-In Patients Communicate And Quadriplegics Control Their World. See http://www.bioethics.upenn.edu/nubc/speakers/surgenor_mindovermachine.pdf

${ }^{30}$ Here is the summary of the event when "science fiction” was turned into reality: Nagle’s skull was oppened using a high-speed drill called a craniotome and using a number 15 scalpel, the protective membranes that surround his brain was carefully sliced through. Magnetic resonance imaging allowed the plotting in advance the region on Nagle's motor cortex most likely to provide readable arm-movement signals to the BrainGate. Using a small pneumatic inserter, the tiny array-100 electrodes, each just 1 millimeter long and 90 microns across at its base-was tapped in. Nagle's skull was closed with titanium screws, leaving a tiny hole. Through that gold wires threaded from the array to an external pedestal connector attached to his skull. In the evening of that fateful day, Nagle's metamorphosis was complete: he was now part biological, and part silicon, platinum, and titanium. A bundle of wires as thick as a coaxial cable runs from a connector in Nagle's scalp to a refrigerator-sized machine. Inside his brain, a tiny array of microelectrodes picks up the cacophony of his neural activity; computer processors recognize the patterns associated with arm motions and translate them into signals that couild be understood by the computer. For a fuller description of the event, and interviews of people involved in Braingate's clinical trial, see Martin, Richard. Mind Control. WIRED Magazine. Issue 13.03 - March 2005. Electronic copy of the article available for download at

http://www.wired.com/wired/archive/13.03/ See also W. Wu, Michael J. Black, Yun Gao, ElieBienenstock, M. Serruya, A. Shaikhouni, John P. Donoghue: Neural Decoding of Cursor Motion Using a Kalman Filter. NIPS 2002: 117-124.

${ }^{31} \mathrm{Ibid}$.

${ }^{32} \mathrm{Ibid}$., about the opening and closing of the prosthetic hand, this was reported in CNN on February 3, 2006. See transcript of the program at http://transcripts.cnn.com/TRANSCRIPTS/0602/03/ltm.03.html [last accessed July 22, 2014, 2:30pm].

${ }^{33}$ As part of its future development, Cyberkinetics plans to hook Brain Gate to stimulators that can activate muscle tissue, bypassing a damaged nervous system entirely. See CNN's special report, dated March 2, 2006, Brain chip research aims for future movement at http://www.cnn.com/2006/TECH/02/22/brain.gate/index.html [last accessed July 22, 2014, 2:30 pm]. Visit the official website of Cyberkinetics and learn more about the Braingate technology at http://www.cyberkineticsinc.com/content/medicalproducts/braingate.jsp. [last accessed July 22, 2014, 2:30 pm] Other future applications of this technology are also discussed there.

${ }^{34}$ I think the best example to illustrate the exponential capability of man in shrinking the sizes of his technology is the shrinking size of the transistor. Consumer Electronics Manufacturers Association reports that Intel's computer chip in 1972 contains 3500 transistors. In 1982, it becomes 134,000; in 1993 the chip contains 3,100,000 transistors; in 1997, it already contains 7,500,000; by 2000, intel's microchip already constains over 10,000,000. With the maturity of Nanotechnology in the next decade, we will be seeing nanotube-based chips, which are already working in laboratories, that build circuits from pentagonal arrays of carbon atoms. One cubic inch of nanotube circuitry would be a million times more powerful than the human brain.
} 
development. To cite two recent examples, a team of Austrian researchers taught a quadriplegic patient to open and close a prosthetic hand using an electrode-studded skullcap that picked up electroencephalograms, waves of electricity generated by the entire brain ${ }^{35}$. And on December of 2004, researchers at the Wads worth Center in Albany, New York, reported that a patient was able to move a cursor around on a monitor using externally detected signals-no implant ${ }^{36}$.

Now that the breakthrough was done, the rest are mere refinement: perfecting the best method that gives the power and clarity one needs to transform the noisy signal of the neurons into something computers can understand and help translate into physical action. The people who question whether brain-computer interface will really work, fails to realize how much has already been done ${ }^{37}$.

Reflecting on all the explosive developments in Science and Technology, most particularly in brain prosthesis and brain-computer interface, I am reminded of Teilhard's idea of telepathy, the direct inter-communication of brains and our link in a sort of "etherized" universal consciousness ${ }^{38}$.

The Law of Accelerating Returns dictates that BCI will end up allowing man to demonstrate this powerthereby removing telepathy from the realm of mysticism. Once done, the language barrier among the peoples of our world would be bridged, and empathy with others would be enhanced as experience may, literally, be shared.

The possibility of a brain-to-brain communications, now being considered in BCI research, points to the direction that far from feeling horror and repugnance, Teilhard might have welcomed this, and other similar technical progress, with the unfailing hope and optimism. Because for Teilhard, regardless of how extreme our projects might be, the measure of its acceptability is the acceptability of the justification we present for its execution. And for Teilhard, there is no other acceptable justification than that it must fulfill the functional needs of reflective action ${ }^{39}$. In short, for the furtherance of collective consciousness.

In so far as Transhumanist concept of biological perfection necessarily leads to greater collective consciousness, Transhumanism, on this fundamental point, finds support in the Philosophy of Teilhard de Chardin.

\section{Teilhard and the Specter of Spiritual Machines}

The fast-growing gulf between technical and moral progress in the world today, causes alarm to many people that there is now a growing demand for either relinquishment of certain areas of technology, or abandoning technological developments altogether ${ }^{40}$.

But Teilhard, if he were still with us today, would have not joined the chorus. For in his time, he has already seen this maelstrom coming, and has penetrated its significance:

"In its early forms human inventive power, as we still see in children, may be likened to a game. In those first manifestations of the power of reflective arrangement, everything appears simple, harmless and even beneficent, giving no hint of a moment to come when we can no longer go on playing. But as the phenomenon spreads and develops within a Mankind in process of becoming adult, what once looked like a game is suddenly found to be deadly earnest. The 'sorcerer's apprentice' by dint of fumbling has laid hands on forces of such power that he begins to be afraid of causing some disaster in Nature. And on the other hand, finding that by his discoveries he has acquired certain keys to the mastery of the world, he begins to realize that if he is to be equal to the situation he is bound, in his role of 'quasi-demiurge', to establish principles

\footnotetext{
${ }^{35}$ Pfurtscheller, G., Flotzinger, D., Mohl W., and Peltoranta, M. Prediction of the side of hand movements from single trial multi-channel EEG data using neural networks. Electroencephalogr Clin Neurophysiol 1992b; 82: 313-315.

${ }^{36}$ J.R. Wolpaw, D.J. McFarland, Control of a two-dimensional movement signal by a non-invasive brain-computer interface in humans, Proc Natl Acad Sci 101: 17849-54. See also Wolpaw, et al., Brain-computer interfaces for communication and control, Clinical Neurophysiology, vol. 113, issue 6, June 2002, pages 767-791.

${ }^{37}$ Among the groundbreaking developments in BCI research include a demonstration that thought could be send via the internet to control robotic arm. Read the December 6, 2000 MIT article of Elizabeth A. Thomson discussing how a monkey, using brain signals sent over Internet, controlled a robotic arm in one of MIT laboratories. Read the article at http://web.mit.edu/newsoffice/2000/monkeys-1206.html [last accessed July 22, 2014, 2:30 pm]; Wheelchair steered by brainpower is currently being developed by European researchers see BBC special report http://news.bbc.co.uk/2/hi/health/3089559.stm [last accessed July 22, 2014, 2:30pm]; A video game in which the character is controlled directly from a player's brain without the need for wires has been developed by researchers read BBC report http://news.bbc.co.uk/2/hi/technology/3485918.stm [last accessed July 22, 2014, 2:30 pm].

${ }^{38}$ The passage I quoted in the first part of this Section: "I am thinking, of course, in the first place of the extraordinary network of radio and television communications which, perhaps anticipating the direct inter-communication of brains through the mysterious power of telepathy, already link us all in a sort of 'etherized' universal consciousness...” see The Future of Mankind, Ch. 6, Part III.

${ }^{39}$ The Future of Mankind, Chapter 13 [3].

${ }^{40}$ See footnote 33 .
} 
and a faith regarding the future and the value of the task that is henceforth imposed upon him., ${ }^{41}$

For indeed clearly, whatever technological wonders we may seek to build will turn to dust if our brilliance is not coupled with conscience and professional integrity, or if our creative temperament is without a rational purpose or goal that it must achieve. But amidst this gap, technological progress must proceed. Because while it is true that Man might misuse the awesome power of his technology and promote, with more efficient means, hatred and disunity ${ }^{42}$, his technological skill will force him into moral maturity. Man, with his godly powers, has no other choice but to grow up and act like god:

"Evolution, in rebounding reflectively upon itself, acquires morality for the purpose of its further advance. In yet other terms, and whatever anyone may say, above a certain level, technical progress necessarily and functionally adds moral progress to itself. All this surely proves that the two events are interdependent. In fact, the pursuit of human knowledge cannot be carried in concrete terms beyond a certain stage without this power of reflective arrangement becoming automatically charged with internal obligations which curb and direct it..."43

As technology and morality are interdependent, allowing the former to proceed will necessarily makes the latter to follow. With the exponential growth of technology, it must be expected that there is a corresponding exponential growth of human spirituality. Today, with the expansion of human senses, thanks to his technology, moral concerns of the individual are also beginning to expand embracing issues that are planetary in its scale. In Teilhard, we see the remarkable application of The Law of Accelerating Returns to moral evolution.

"Our modern world was created in less than 10,000 years, and in the past 200 years it has changed more than in all the preceding millennia. Have we ever thought of what our planet may be like, psychologically, in a million years' time?"44

In a million years, man will be beyond recognition, both in form and in spirituality: human consciousness may finally decide to disgorge its flesh and bones-the edifice it has known when it was young - in exchange for metal and plastic.

However, although Man may extend his existence by attacking the causes of his mortality at the root; or although he may go elsewhere and continue his destiny in some other corner of the firmament of deep space, it will just be a matter of time-regardless of its immensity-when human consciousness will finally realize that survival in the material universe is irrelevant to events and processes on a cosmological scale. Stars are born and die; galaxies go through their cycles of creation and destruction. The Universe itself was born in a big bang and will end with a crunch or a whimper, we're not yet sure which ${ }^{45}$. The mechanism of the universe is winding up or down to a distant future. The Universe will die, and it's death brings along with it the death of any and all immortals it contains. In short, in so far as the Universe is a physical universe, the concept of "immortality" is an absurdity.

Gradually, man, in his ultimate form, will then realize salvation not in the direction of any temporal or spatial consolidation or expansion but only by way of spiritual escape through the excess of consciousness.

"At the end of its totalization, its folding-in upon itself, Mankind reaches a critical level of maturity where, leaving Earth and stars to lapse slowly back into the dwindling mass of primordial energy, it will detach itself from this material universe and join the one true, irreversible essence of things, the Omega point." ${ }^{46}$

When that day comes, the evolution of man is complete. Man, according to Teilhard, finally unites with God, who created and shaped man through evolution, and who patiently waited for the moment when man finally arises from the world ${ }^{47}$.

\footnotetext{
${ }^{41}$ The Future of Mankind, Ch. 6 [3].

${ }^{42}$ Brain-Computer Interface, unfortunately, can also redefine how mankind wages its future Wars. Here's how Anthony Tether, the director of Darpa, envisioned the military outcome of BCI research: "Imagine 25 years from now where old guys like me put on a pair of glasses or a helmet and open our eyes. Somewhere there will be a robot that will open its eyes, and we will be able to see what the robot sees. We will be able to remotely look down on a cave and think to ourselves, 'Let's go down there and kick some butt.' And the robots will respond, controlled by our thoughts. Imagine a warrior with the intellect of a human and the immortality of a machine." See Wired Magazine, Issue 13.03, March, 2005, http://www.wired.com/wired/archive/13.03/ [last accessed July 22, 2014, 2:30 pm].

${ }^{43}$ The Future of Mankind, Chapter 13 [3].

${ }^{44}$ Ibid. Ch. 4, Part I [7]. Teilhard added, "Here, it is finally the Utopians, not the 'realists', who make scientific sense. They at least, though their flights of fancy may cause us to smile, have a feeling for the true dimensions of the phenomenon of Man."

${ }^{45}$ What the astronomers call "Dark Era" is one of the two versions of how the whole universe will finally end in 100 trillion years time. Astronomers assume that the universe will gradually wither away, provided it keeps on expanding, or it recollapse, in a "Big Crunch", under the pull of its own gravity.

${ }^{46}$ The Future of Man, Ch. 6, Part IV.

${ }^{47}$ Ibid., Ch. 4, Part II [2].
} 


\section{Conclusion: Towards an Ethics of Technology}

Teilhard's philosophy does not thread the traditional religious lines describing the human body as a sacred sanctuary that must be untouched except in extreme cases. For Teilhard, the human body is a cradle which consciousness must rise above in order to fulfill the next step of the evolutionary process. Man is therefore, not only allowed, but tasked to enhance it, or to sublime it, if doing so would further this purpose.

This paper has shown that for Teilhard, the purpose of evolution is greater consciousness, and those which satisfy the purpose of evolution are ethical.

Matter, we have argued in the very beginning of this paper, is the edifice, the cradle of consciousness. Consciousness becomes more perfected as it finds a richer and better organized material structure. Matter can be enhanced by human technology, and as such, technology-assisted enhancement of matter satisfies the purpose of evolution. Since technology-assisted enhancement of matter satisfies the purpose of evolution, then, technologyassisted enhancement of matter is ethical.

And by matter, we mean the entire human body, including the brain.

We have emphasized the brain because as Teilhard has clearly and strongly argued, it is the sign and measure of consciousness. The more the nervous system develops, the more conscious the living entity becomes. The enhancement of the human brain means the enhancement of consciousness. If the purpose of evolution is greater consciousness, and if technology-assisted enhancement of the human brain means the enhancement of consciousness, then enhancement of the human brain is ethical.

The convergence of human reflective powers with inherent superiority in the speed, accuracy, and sharing ability of computers provides for the physical possibility of a truly "collective" thought.

Social ills and havoc wrought by technology are also explained away as necessary cost of mankind's unstoppable or inevitable evolution towards greater consciousness. Reflecting in the age when the fearsome power of the atom was first unleashed in the face of the Earth, Teilhard offered this remarkable insight:

"Thus considered, the fact of the release of nuclear energy, overwhelming and intoxicating though it was, began to seem less tremendous. Was it not simply the first act, even a mere prelude, in a series of fantastic events which, having afforded us access to the heart of the atom, would lead us on to overthrow, one by one, the many other strongholds which science is already besieging? The vitalization of matter by the creation of super-molecules.The re-modeling of the human organism by means of hormones. Control of heredity and sex by the manipulation of genes and chromosomes... It is thus, step by step, that Man, pursuing the flight of his growing aspirations, taught by a first success to be conscious of his power, finds himself impelled to look beyond any purely mechanical improvement of the earth's surface and increase of his external riches, and to dwell upon the growth and biological perfection of himself."

BCI and other revolutionary technologies, are just the various means of man in fulfilling his task of consciously accomplishing the goal of evolution. Clearly therefore, human technology in general, far from dehumanizing him, are, for Teilhard, catapulting him to higher heights of consciousness, to greater union with the rest of his kind, in short towards planetization, towards totalization. If this is the case, then the entire prospect of the coming convergence of biological and non-biological intelligence, are things that must not be feared, but welcomed with calm and confidence.

This premise holds, even in the midst of the "apparently” widening gap between our technical ability and moral maturity. Science and Technology must be allowed to proceed, because as we develop scientifically and technologically, we are forced to grow up. And as we become more morally matured, we will discover ourselves how technology should be used, what technology should be pursued, and what technology is too dangerous that it must be abandoned.

In the Philosophy of Teilhard, the prospect of all these technologies lead to the creation of super-humans or immortal-humans is something that must not be feared. Because humans in their ultimate or perfect form will realize that physical escape in the coming end of his physical universe will not be possible. Salvation can be achieved NOT in the direction of any temporal or spatial consolidation or expansion but only by way of spiritual escape... something that his technology can never provide.

And here, lies the real strength of Teilhard"s philosophy-His philosophy synthesized the best of science and religion by providing the former with an ideal to be reached, and the latter with basic factual objective. It tran-

${ }^{48}$ Ibid., Chapter 8 [b-c]. 
scends and gives meaning even to the ultimate transhumanist challenge, that it may truly be considered the philosophy of the future.

\section{Acknowledgements}

My heartfelt thanks to Dr. Romeo R. Quilang, University President, Cagayan State University and to Dr. Jose P. Guzman, Vice-President for Research and Extension, Cagayan State University, for their selfless support.

\section{References}

BBC NEWS. Wheelchair Steered by Brainpower. Published: 2003/07/24 10:04:06 GMT http://news.bbc.co.uk/2/hi/health/3089559.stm

Brin, D. (2006). Singularities and Nightmare in Nanotechnology Perceptions: A Review of Ultraprecision Engineering and Nanotechnology, Volume 2, No. 1. http://www.kurzweilai.net/meme/frame.html?main=/articles/art0656.html

Clarke, A. (1999). 2001: A Space Odyssey. New York: New American Library.

Clarke, A. (1953). Childhood's End. New York: Random House Publishing Group.

Clarke, A. (2001). Fountain of Paradise. London: Victor Gollancz Ltd.

CNN Science Report, February 3, 2006. http://transcripts.cnn.com/TRANSCRIPTS/0602/03/ltm.03.html

CNN's Special Report, Dated March 2, 2006, Brain Chip Research Aims for Future Movement at http://www.cnn.com/2006/TECH/02/22/brain.gate/index.html

Constans, A. Mind over Machines: Brain-Machine Interfaces Help Locked-In Patients Communicate and Quadriplegics Control Their World. http://www.bioethics.upenn.edu/nubc/speakers/surgenor_mindovermachine.pdf

de Chardin, T. (1959). The Future of Mankind. New York: Harper \& Row Publishers.

de Chardin, T. (1975). The Phenomenon of Man. New York: Harper \& Row Publishers, 243.

Fukuyama, F. (2002) Transhumanism. in Foreign Policy September-October 2004. http://www.foreignpolicy.com/story/cms.php?story id=2667

Fukuyama, F. (2002). Posthuman Future: Consequences of the Biotechnology Revolution. New York: Pan Books Limited.

Joy, B. (2002). Why The Future Does Not Need Us. Wired Magazine, Issue 8.04. http://www.wired.com/wired/archive/8.04/

Kurzweil, R. (1999). The Age of Spiritual Machines: When Machine Intelligence Exceeds Human Intelligence. London: Penguin Book, Ltd., 8.

Martin, R. (2005). Mind Control. WIRED Magazine. Issue 13.03, March 2005. http://www.wired.com/wired/archive/13.03/

Moravec, H. (1988). Mind Children: The Future of Robot and Human Intelligence. Cambridge, MA: Harvard University Press.

Moscovitch, M., Thomspon, E., \& Zelato, P. D. (2007). Handbook of Consciousness. Cambridge: Cambridge University Press.

Pfurtscheller, G., Flotzinger, D., Mohl, W., \& Peltoranta, M. (1992). Prediction of the Side of Hand Movements from Single Trial Multi-Channel EEG Data Using Neural Networks. Electroencephalography and Clinical Neurophysiology, 82, 313315. http://dx.doi.org/10.1016/0013-4694(92)90112-U

Thomson, E. A. (2014). Monkey Controls Robotic Arm Using Brain Signals Sent over Internet. Massachusetts Institute of Technology. http://web.mit.edu/newsoffice/2000/monkeys-1206.html

Toffler, A. (1972). Future Shock. New York: Bantam Books.

Toffler, A. (1980). Third Wave. New York: Bantam Books.

Twist, J. (2004). Brain Waves Control Video Game. BBC News Online Technology Reporter. http://news.bbc.co.uk/2/hi/technology/3485918.stm

Wolpaw, J. R., \& McFarland, D. J. (2004). Control of a Two-Dimensional Movement Signal by a Non-Invasive Brain-Computer Interface in Humans. Proceedings of the National Academy of Sciences of the United States of America, 101, 1784917854. http://dx.doi.org/10.1073/pnas.0403504101

Wolpaw, J. R., Birbaumer, N., McFarland, D. J., Pfurtscheller, G., \& Vaughan, T. M. (2002). Brain-Computer Interfaces for Communication and Control. Clinical Neurophysiology, 113, 767-791. http://dx.doi.org/10.1016/S1388-2457(02)00057-3

Wu, W., et al. (2002). Neural Decoding of Cursor Motion Using a Kalman Filter. NIPS: 117-124. 
Scientific Research Publishing (SCIRP) is one of the largest Open Access journal publishers. It is currently publishing more than 200 open access, online, peer-reviewed journals covering a wide range of academic disciplines. SCIRP serves the worldwide academic communities and contributes to the progress and application of science with its publication.

Other selected journals from SCIRP are listed as below. Submit your manuscript to us via either submit@scirp.org or Online Submission Portal.
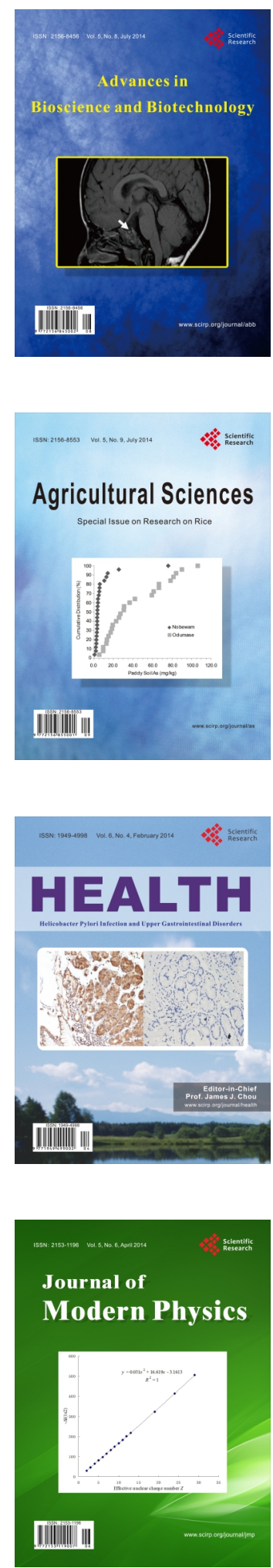
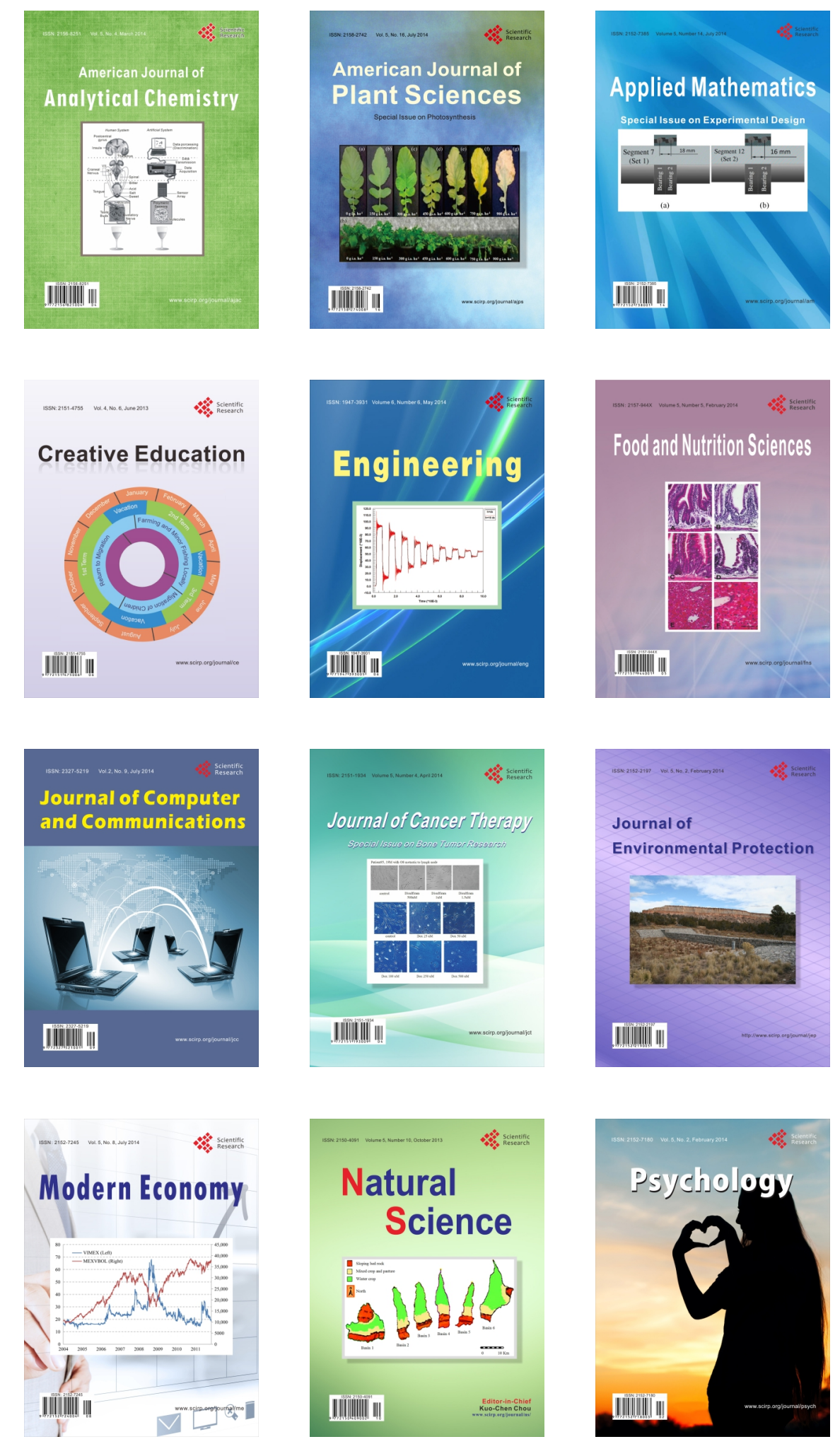